\section{READERS nsight}

Journal of Management Info (JMI)

ISSN:2313-3376

www.readersinsight.net/jmi

\title{
The impact of trainings on skill development and anxiety reduction of teachers in public sector colleges in Khyber Pakhtunkhwa, Pakistan
}

\author{
Arab $\mathrm{Naz}^{1 *}$, Nasim Khan², Faisal Khan ${ }^{3}, \mathrm{Nasar}_{\mathrm{Khan}}{ }^{4}$, Javaria Raza ${ }^{5}$, Waliullah ${ }^{6}$ \\ ${ }^{1}$ Department of Sociology and Social Work, University Malakand, Pakistan \\ 2 Department of Sociology Allama Iqbal Open University, Islamabad \\ ${ }^{3}$ Department of Management Studies, University of Swat, Pakistan \\ ${ }^{4,6}$ Department of Sociology and Social Work, University Malakand \\ ${ }^{5}$ Department of Sociology University of Peshawar \\ *Corresponding author: arab_naz@yahoo.com
}

\begin{abstract}
Training is an important source of development of work force in an organization whether its business, educational or sports related organization (Nadeem, 2010). The current research activity is an effort to study the impact of trainings on job performance of teachers in public sector colleges in Khyber Pakhtunkhwa. The study is purely quantitative in nature and conducted in Malakand Division, Khyber Pakhtunkhwah, Pakistan. Probability sampling technique has been adopted for sampling specifically stratified random sampling while a structured questionnaire based on Likert five category scales has been utilized to collect information from the selected samples. Besides, the data has been analysed in tabular form including frequency and percentage against each category of opinion. In addition, chisquare test has been applied to in order to check association among variables. The process of data analysis has been done through a computer based software (SPSS). Findings of the study reveal that training significantly affects performance of teachers at college level. In this regard, numerous indicators have been discussed and analysed and the results indicate that trainings plays a positive role in learning and enhancing their capacity to perform and reduce job related stress and anxiety.
\end{abstract}

ARTICLE INFORMATION

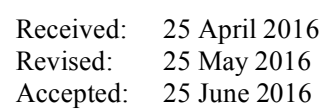

Accepted: 25 June 2016

DOI:

http://dx.doi.org//10.31580/jmi.v10i1.51

\section{Background of the study}

Training is an imperative aspect related to modern organizational structure, preferably due to the fact that it is source of polishing the capabilities and skills of individuals. Training is an activity which helps the individuals to adopt as well as understand organizational structure (Bumpass, 1990). In this regard, training makes able the employees to adopt, cope and learn about the organizational structure, policies and process through acquisitions of skills and knowledge. Training is about knowing where an employee stand (no matter how good or bad the current situation looks) at present and where the employee will be after some point of time. The activities and processes carried out in training is a source of bringing changes in an individual by providing them with certain defined skills or assist them to reduce deficiencies in their performances (Gomez et al., 2011). Training includes practices which affects organizational outcomes by modifying and shaping trainees behaviours and attitudes (Richard, Thacker \& Way, 2002). Training usually are based on programs which are aimed to build the capabilities of employees, empower them to strap up their true human social-economic potential for enhancing their quality of life. Therefore, training has an eminent role in the succeeding an organization (Bassi and Van Buren, 1999). In other words, training is a mean, which fills the gap between job requirement and an employee's current specifications where fulfilment of job requirement leads to advancement in performance. Training is a source of enhancing presentation skills; boost in motivational level (Tharenou, Saks and Moore, 2007) adjustment in attitude as well as reduction in conflicting thoughts (Bumpass, 1990); increase in commitment and job satisfaction (Sahinidis \& Bouris, 2008); and, lastly, enthusiasm (Tabassi, Mahyuddin and Hassan, 2012). Besides, research also reveals that training is vital for teachers and employees during the course of their job due to the fact that training is helpful in reducing level of anxiety at job or working place, increases self-efficacy along with increase in level of job involvement (Colquitt, LePine and Noe, 2000) and increases confidence level (Santos, 2003). Additionally, training increases consistency level and confidence to maintain, upgrade and update skills throughout working life (Tharenou, Saks and Moore, 2007). Thus, the discussion concludes that training is an important aspect for the improvement of overall job performance of teachers.

As organizations strive to compete in the global economy, differentiation on the basis of the skills, knowledge, and motivation of their workforce takes on increasing importance. According to a recent industry report by the American Society for Training and Development (ASTD), U.S. organizations alone spend more than $\$ 126$ billion annually on employee training and development (Paradise, 2007). "Training" refers to a systematic approach to learning and development to improve individual, team, and organizational effectiveness such as increase in ability to provide standard education (Goldstein and Ford, 2002).

Training is of many types; firstly, specific objective training which refers to training given to an individual or group of individual in order to improve their performance regarding a specific aspect such as training given to teacher with regard to improve method of their 
teaching. Secondly, general training which refers to training given to a person in order to improve his general level of communication, potential and capability. For example, training given to an individual in order to enhance his/her overall behaviour (Hinkim, and Schriesheim, 2004).

In specific relevance to the current study, government provides training to teaching as well as administrative faculty in graduate and post graduate colleges. In this regard, general and specific training are given to teachers in colleges including training that how to teach, manage and keep up with their jobs (Taylor, Russ, and Chan , 2005). Training and development of teachers and administration include in one of the basic and primary aims of educational department Khyber Pakhtunkhwa. In this connection, training is a source of providing expert teachers and administration in order to ensure standardized quality education. Teachers and administration in colleges need to be habitual with the rules, norms and ethos of the society in order to transfer tit o future generation. Thus, in the promising and emerging scenario, the extent, need, scope as well as execution of teacher training has been considerably widened, hence, the training strategy needs a renewed impetus to meet the impending demands. Further, various types of training are arranged for teachers of colleges including under Directorate of Curriculum and Teacher Education, Provincional Institute of Teacher Education and Regional Institution for Teacher education (Higher Education Department KPK, 2014).

\section{Statement of the problem}

Training is a complex phenomenon which is affected by numerous factors. The success or failure of training is dependent on multidimensional aspects such as management of the training can motivates or de-motivate participants of training (Janaki. and Vaishnavi, 2012). Subjects and the transfer of the training is one of the basic considerations while taking into account the impacts of training on training participants (Baldwin \& Magjuka, 1988). In addition, the participants of training themselves are key to results produced by training, for example, talent as well as mentality of the training participants is necessary due to the fact that each and every person have own kind of talent and mentality (Rama \& Vaishnavi, 2012). Level of motivation is important both for the trainer and the trainees which influence the results of training. Further, objectives, purpose, level of open-mindedness of the trainers as well as trainees, and attitude along with approach of the participants are the major determining factors in making the training effective (Saks and Haccoun, 2007).

Training is one of the essential organizational components where training is a necessary activity for an organization to compete with modern organizations. Training is linked with up gradation in capabilities, potentialities and skills of employees, which leads to improvement in job performance. Such enrichment makes an organization accomplished of achieving objectives, objectives and increases production. Beyond, training is also associated with improvement in job performance of employees, which have its own fruits. In this milieu, the current study aims to recognize the impacts of training on the presentation of employees during job, which is an imperative organizational aspect. The study will analyse different training dimensions, which contributes to improvement in job presentation of employees.

\section{Objectives of the study}

1. To identify the role of training in organizational management of employees

2. To explore the level of effectiveness of training in organization 3. To analyse the various impact of satisfaction of trainings on reducing job related stresses

\section{Hypotheses of the study}

H1:Organizational training enhanced managerial skills of teachers in colleges

H2: Organizational training is associated with reduction in job related stress and anxiety

\section{Theoretical framework}

Theoretical framework refers to the structure that can hold or support a theory of a research study. The theoretical framework introduces and describes the theory that explains why the research problem under study exists (Nueman, 2006). The current research is guided by Kirkpatrick model (1976). The model consists of the following indicators:s

\section{Reaction}

Instructor

Presentation St

Training Topics

Training Materi

\section{Schedule of Training}

\section{Enhancement in organizationá skills and reduction in anxiety}

\section{Methodology}

\section{Nature of the study}

The current study is of quantitative nature which according to Babbie (2012) is a type of inquiry explaining phenomena by gathering numerical data analyzed using mathematically based methods e.g. statistics. Quantitative research design refers to the numerical representation, manipulation and analysis of data i.e. the use of statistical and mathematical tools is dominant in such design. In other words, quantitative research is the game of numbers (Denzin, 1978).

\section{Sampling}

Sampling refers to the selection of unit/units from population through specific devised method. It is an important aspect related to any research activity based on different methods such as probability and non-probability sampling (Babbie, 2012; Dawson, 2002). For the current study, the researcher have used proportionate stratified random sampling i.e. to is a type of probability sampling in which the population is divided into mutually exclusive and mutually exhaustive subgroups/strata and then taking a simple random sample in each subgroup/strata. This type of sampling is also called proportional or quota random sampling (Singh, 2007).

In a similar context, the researcher has selected 200 samples on the basis of proportional allocation method as suggested by (Nueman, 2006) from graduate and post-graduate colleges of Malakand Division. At first, all the population of teachers who have attained at least ten days training were obtained. In this regard, from each 
college, a sample of selected members was obtained using proportional allocation formula given below.

$\mathrm{nh}=\mathrm{n} / \mathrm{L}$

Where $\mathrm{nh}=$ sample size in stratum

$\mathrm{n}=$ total sample size

$\mathrm{L}=$ strata

Besides, the following table includes sampling details used in the current study:

\section{Sample Frame}

\begin{tabular}{|l|l|l|l|}
\hline $\begin{array}{l}\text { Name of the } \\
\text { college }\end{array}$ & $\begin{array}{l}\text { Total } \\
\text { Population of } \\
\text { the Strata }\end{array}$ & $\begin{array}{l}\text { Population } \\
\text { sampled } \\
\text { from } \\
\text { strata }\end{array}$ & $\begin{array}{l}\text { Sampling } \\
\text { technique }\end{array}$ \\
\cline { 1 - 3 } $\begin{array}{l}\text { Jehanzeb } \\
\text { College Swat }\end{array}$ & 123 & 50 & \multirow{2}{*}{$\begin{array}{l}\text { Proportional } \\
\text { allocation } \\
\text { method }\end{array}$} \\
\cline { 1 - 2 } $\begin{array}{l}\text { Government } \\
\text { degree college } \\
\text { Thana }\end{array}$ & 102 & 50 & \\
\cline { 1 - 2 } $\begin{array}{l}\text { Government } \\
\text { degree college } \\
\text { Gulabad }\end{array}$ & 89 & 50 & \\
\cline { 1 - 2 } $\begin{array}{l}\text { Government } \\
\text { degree college } \\
\text { Timergara }\end{array}$ & 112 & 50 & \\
\cline { 1 - 2 } Total & 426 & 200 & \\
\hline
\end{tabular}

\section{Data collection and tool of data collection}

Data collection includes in one of the important steps in research process which is a stage in the research process where information is gathered through different means i.e. questionnaire, interview schedule or observation (Singh, 2007). In a similar context, the means through information is gathered during research process is known as tool of data collection. Thus, the current study utilized Likert scale questionnaire as a tool of data collection.

\section{Data analysis}

As discussed earlier that the current study is quantitative in nature; thus, the current step during conduction of the study i.e. data analysis is also quantitative in nature In explanation, quantitative data is a numerical evidence or record that results from a course of measurement and on which basic mathematical operations can be done. Thus, the current study presents the analysed data in quantitative i.e. cross-tabular form along with application of chisquare test. Further, the tables include percentage and frequencies to each category of opinion.

\section{Results and discussions}

\section{Age wise distribution of respondents}

According to Word Web (2014), age refers to "How long something has existed". Age is a biological characteristic of all living organism and is a continued process all the time. Age is very important factor related to everything; thus, the current study considers age as an important component. The following table contains age wise distribution of respondents:

Table 01: Age wise Distribution of Respondents

\begin{tabular}{|l|l|l|}
\hline $\begin{array}{l}\text { Age } \\
\text { group }\end{array}$ & Frequency & Percentage \\
\hline $21-30$ & 30 & 15 \\
\hline $31-40$ & 83 & 41.5 \\
\hline
\end{tabular}

\begin{tabular}{|l|l|l|}
\hline $41-50$ & 69 & 34.5 \\
\hline $\begin{array}{l}51 \\
\text { and } \\
\text { above }\end{array}$ & 18 & 9 \\
\hline Total & $\mathbf{2 0 0}$ & 100 \\
\hline
\end{tabular}

Regarding age of the respondents, statistical analysis of the tabular information indicates that $30(15 \%)$ of the respondents belonged to age category of $21-30$. Majority that is $83(41.5 \%)$ of the respondents were in the age category of $31-40$ while $69(34.5 \%)$ of the respondents belonged to age category of 41-50. Few, however, an important portion such as $18(9 \%)$ of the respondents belonged to age category of 51 and above.

\section{Gender wise distribution of respondents}

Gender is a very important socio-cultural concept. Gender refers to the culturally and socially constructed differences between females and males found in the meanings, beliefs, and practices associated with "femininity" and "masculinity" (Kendall, 2007). The following table includes information regarding gender wise distribution of respondents:

Table 2: Gender wise Distribution of Respondents

\begin{tabular}{|l|l|l|}
\hline Gender & Frequency & Percentage \\
\hline Male & 177 & 88.5 \\
\hline Female & 23 & 11.5 \\
\hline Total & $\mathbf{2 0 0}$ & 100 \\
\hline
\end{tabular}

Information regarding gender wise distribution of respondents shows that a significant majority that is $177(88.5 \%)$ respondents were male while little however an important portion such as $23(11.5 \%)$ respondents were female.

\section{Educational status of respondents}

According to the report of Medical Information National Library of Medicine (2012) educations status refers to "Educational attainment or level of education of individuals". Thus, educational status can be defined as the amount of education an individual have such as primary, matriculate, graduate to post graduate level education. In this regard, the following table contains information regarding education status of respondents:

Table 3: Educational Status of Respondents

\begin{tabular}{|l|l|l|}
\hline $\begin{array}{l}\text { Educational } \\
\text { Status }\end{array}$ & Frequency & Percentage \\
\hline Middle & 00 & 00 \\
\hline Metric & 13 & 6.5 \\
\hline Inter & 19 & 9.5 \\
\hline Bachelor & 56 & 28 \\
\hline $\begin{array}{l}\text { Master or } \\
\text { above }\end{array}$ & 112 & 56 \\
\hline Total & $\mathbf{2 0 0}$ & $\mathbf{1 0 0}$ \\
\hline
\end{tabular}

Regarding educational status of respondents the tabular information enumerates that none of the respondents were illiterate. $13(6.5 \%)$ respondents were educated up to metric level. $19(9.5 \%)$ respondents were educated up to intermediate level. A reasonable portion i.e. 56 $(28 \%)$ respondents were educated up to bachelor level while majority 
that is $112(56 \%)$ respondents were educated up to masters level or above.

\section{Designation of respondents}

According to Word Web (2015), the term designation refers to the job position of a person or the status of a person at work place. The current study includes designation is an important aspect whereby the following table contains information regarding designation of the respondents:

Table 4: Designation of Respondents

\begin{tabular}{|l|l|l|}
\hline $\begin{array}{l}\text { Designation } \\
\text { of } \\
\text { respondents }\end{array}$ & Frequency & Percentage \\
\hline peon & 15 & $7.5 \%$ \\
\hline Clerk & 46 & $23 \%$ \\
\hline Administration & 87 & $43.5 \%$ \\
\hline Teaching & 52 & $26 \%$ \\
\hline Total & 200 & 100 \\
\hline
\end{tabular}

Designation is a pivotal aspect in relation to assessing the impacts $(7.5 \%)$ respondents were peon while $46(23 \%)$ respondents were ordelivery and the post of clerks. A reasonable majority e.g. 87 (43.5\%) respondentsommunication were on administrative posts and $52(26 \%)$ respondents werekills involved in field of teaching.

\section{Type of training received}

According to Becker (1964), there are two types of training. The first one is specific objective training which is given to an employedotal by an organization to train him regarding a particular job. The second one is general training which refers to training given to a person in order to improve his general level of communication, potentials and capability. General training leads to improvement and enhancement in skills which can be utilized any where i.e. communication skill (Konings and Vanormelingen, 2010). Similarly, type of training received is an eminent aspect related to the current research activity. Thus, the type of training received by an employee is given in the table below:

Table 5: Type of Training Received

\begin{tabular}{|l|l|l|}
\hline $\begin{array}{l}\text { Type of } \\
\text { Training } \\
\text { received }\end{array}$ & Frequency & Percentage \\
\hline General & 29 & $14.5 \%$ \\
\hline Specific & 80 & $40 \%$ \\
\hline $\begin{array}{l}\text { Multiple } \\
\text { trainings } \\
\text { i.e. } \\
\text { availed } \\
\text { both } \\
\text { general } \\
\text { and } \\
\text { specific }\end{array}$ & 91 & $45.5 \%$ \\
\hline Total & $\mathbf{2 0 0}$ & $\mathbf{1 0 0} \%$ \\
\hline
\end{tabular}

As mentioned that type of training received by respondents is an important aspect related to the current study; relevantly, the statistical analysis of the tabular information shows that respondents have received all types of training. In this context, 29 (14\%) respondents have received general training while $80(40 \%)$ respondents have received specific training. However, majority i.e. 91 (45.5\%) respondents have received multiple trainings such as they have availed both general and specific types of training.

\section{Reaction towards instructor and presentation style}

Instructor has a significant role in providing a successful and effective training. Instructor is the responsible person for the transfer of knowledge during training. The presentation style of instructor is vital to the transfer of knowledge from instructor to the trainees (Barber \& Mourshed, 2007). Further, the knowledge and presentation skill of instructor depends on the skill, qualification as well as the experience of the instructor (Hanushek, 2003; Barber \& Mourshed, 2007; Varga, 2007). In a similar context, table no 01 explains the reaction of training participants to instructor as well as presentation style of the instructor.

Table 06: Reaction towards Instructor and Presentation Style

\begin{tabular}{|c|c|c|c|c|c|c|}
\hline Statements & $\begin{array}{l}\text { Strongly } \\
\text { Agree }\end{array}$ & Agree & $\begin{array}{l}\text { No } \\
\text { opinion }\end{array}$ & Disagree & $\begin{array}{l}\text { Strongly } \\
\text { Disagree }\end{array}$ & Total \\
\hline $\begin{array}{l}\text { The instructor } \\
\text { has sufficient } \\
\text { knowledge }\end{array}$ & $\begin{array}{l}23(11.5 \\
\%)\end{array}$ & $\begin{array}{l}11 \\
(5.5 \\
\%)\end{array}$ & $\begin{array}{l}00(00 \\
\%)\end{array}$ & $02(1 \%)$ & $\begin{array}{l}03(1.5 \\
\%)\end{array}$ & $\begin{array}{l}39 \\
(19.5 \\
\%)\end{array}$ \\
\hline $\begin{array}{l}\text { OFe instructor } \\
15 \text { have good } \\
\text { ordelivery and } \\
\text { tsommunication } \\
\text { rEkills }\end{array}$ & $\begin{array}{l}71(35.5 \\
\%)\end{array}$ & $\begin{array}{l}07 \\
(3.5 \\
\%)\end{array}$ & $\begin{array}{l}00(00 \\
\%)\end{array}$ & $\begin{array}{l}05(2.5 \\
\%)\end{array}$ & $\begin{array}{l}13(6.5 \\
\%)\end{array}$ & $\begin{array}{l}96 \\
(48 \\
\%)\end{array}$ \\
\hline $\begin{array}{l}\text { The instructor } \\
\text { was well } \\
\text { qualified } \\
\text { he }\end{array}$ & $\begin{array}{l}29(14.5 \\
\%)\end{array}$ & $\begin{array}{l}22(11 \\
\%)\end{array}$ & $\begin{array}{l}03(1.5 \\
\%)\end{array}$ & $10(5 \%)$ & $\begin{array}{l}01(0.5 \\
\%)\end{array}$ & $\begin{array}{l}65 \\
(32.5 \\
\%)\end{array}$ \\
\hline $\begin{array}{l}\text { eđotal } \\
\text { nd } \\
\text { in }\end{array}$ & $\begin{array}{l}123 \\
(61.5 \%)\end{array}$ & $\begin{array}{l}40(20 \\
\%)\end{array}$ & $\begin{array}{l}03(1.5 \\
\%)\end{array}$ & $\begin{array}{l}17(18.5 \\
\%)\end{array}$ & $\begin{array}{l}17(18.5 \\
\%)\end{array}$ & $\begin{array}{l}200 \\
(100 \\
\%)\end{array}$ \\
\hline
\end{tabular}

Field information provided in the table no. 01 explains the reaction of training participants towards instructor and presentation style. Presentation style of instructors is judged through different variables given as statements in the table. In this regard, the first statement analyses that whether instructor had the sufficient knowledge or not. The response in shape of percentages shows that $11.5 \%$ respondents strongly agreed with the statement while $10.5 \%$ agreed with the statement. The second statement give in the table is about delivery and communication skill of the instructor where majority i.e. $35.5 \%$ respondents strongly agreed that the instructor got good delivery and communication skills. Finally, $14.5 \%$ respondents strongly agreed that the instructors were well qualified while $11 \%$ just agreed with the statement.

Besides, the cross comparison validates that instructors and their presentation skills were satisfactory for the training participants. In this context, in the column wise distribution, $61.5 \%$ respondents strongly agreed with statements given in the table while $20 \%$ agreed. Thus, a total of $81.5 \%$ respondents were satisfied from the instructors and their presentation skills. Besides, in row wise distribution $48 \%$ of respondents selected the statement about the delivery and communication skills of the instructor. In addition, the chi-square test validates the argument that skills and presentation style of trainers have an important role in effectiveness of training. The chi-square value of 4.564 having degree of freedom of 08 shows significance of the argument. 
The discussion thus concludes that reaction of participants towards instructors and presenters was reasonably good. In explanation, trainees argued that instructors were having sufficient knowledge with appropriate qualification and good delivery skills.

\section{Training and skill development}

Skill development is the most pivotal aspects related to training. The concept of measuring the degree of learning as a result of training have a basic aim which is specific learning objectives is a basic of any training program. In addition, it is evident from literature that training and related changes should lead to improved job performance and other positive changes such as acquisition of new skills. These new skills can be job specific as well as general improvement in an individual. The components of such skills include communication as well as skill of coping with difficult situations during job and at work place (Hill \& Lent 2006; Satterfield \& Hughes, 2007). In accordance, the field information provided in the table given below explicates about the skill development of respondents as a result of training participation (see the table below)

Table 7: Training and Skill development

\begin{tabular}{|c|c|c|c|c|c|}
\hline Statements & $\begin{array}{l}\text { Strongl } \\
\text { y Agree }\end{array}$ & $\begin{array}{l}\text { Agre } \\
\mathrm{e}\end{array}$ & $\begin{array}{l}\text { No } \\
\text { opinio } \\
\text { n }\end{array}$ & $\begin{array}{l}\text { Disagre } \\
\mathrm{e}\end{array}$ & $\begin{array}{l}\text { Strongl } \\
\text { y } \\
\text { Disagre } \\
\text { e }\end{array}$ \\
\hline $\begin{array}{l}\text { Training has } \\
\text { enhanced } \\
\text { your } \\
\text { communicatio } \\
\text { n skills }\end{array}$ & $\begin{array}{l}21(10.5 \\
\%)\end{array}$ & $\begin{array}{l}13 \\
(6.5 \\
\%)\end{array}$ & $\begin{array}{l}00(00 \\
\%)\end{array}$ & $\begin{array}{l}00(00 \\
\%)\end{array}$ & $\begin{array}{l}00(00 \\
\%)\end{array}$ \\
\hline $\begin{array}{l}\text { Training has } \\
\text { enhanced } \\
\text { your skill } \\
\text { regarding } \\
\text { specific job } \\
\text { task }\end{array}$ & $\begin{array}{l}81(40.5 \\
\%)\end{array}$ & $\begin{array}{l}45 \\
(22.5 \\
\%)\end{array}$ & $\begin{array}{l}04(02 \\
\%)\end{array}$ & $\begin{array}{l}06(03 \\
\%)\end{array}$ & $\begin{array}{l}04(02 \\
\%)\end{array}$ \\
\hline $\begin{array}{l}\text { Training has } \\
\text { enhanced } \\
\text { your skills to } \\
\text { cope with } \\
\text { difficult } \\
\text { situations }\end{array}$ & $\begin{array}{l}09(4.5 \\
\%)\end{array}$ & $\begin{array}{l}13 \\
(6.5 \\
\%)\end{array}$ & $\begin{array}{l}03(1.5 \\
\%)\end{array}$ & $\begin{array}{l}01(0.5 \\
\%)\end{array}$ & $\begin{array}{l}00(00 \\
\%)\end{array}$ \\
\hline Total & $\begin{array}{l}111 \\
(55.5 \\
\%)\end{array}$ & $\begin{array}{l}71 \\
(35.5 \\
\%)\end{array}$ & $\begin{array}{l}07(3.5 \\
\%)\end{array}$ & $\begin{array}{l}07(3.5 \\
\%)\end{array}$ & $\begin{array}{l}04(02 \\
\%)\end{array}$ \\
\hline
\end{tabular}

Skill development is an essential component of training objective Rnowledge $_{\text {nour }}$ whereby the statistical information given the table indicates that skildbout the of an individual is improved after participating in training. In thisob regard, various indicators have been discussed in the above tahle where the first indicator is the enhancement in communication skills Training after participation in training. $34(17 \%)$ respondents opted for the has indicator whereby $21(10.5 \%)$ and $13(6.5 \%)$ respondents strongly changed agreed and agreed with the indicator respectively. Further, none of thyour respondents disagreed with the indicator which strongly indicates thatowards job communication skill of trainees is enhanced after training conduction. A reasonable majority i.e. $140(70 \%)$ respondents viewed thaTraining training has enhanced their skills regarding a specific job whereby 8 has $(40.5 \%)$ and $45(22.5 \%)$ respondents strongly agreed and agreedncreased with statement respectively. However, $04(02 \%), 06(03 \%)$ and your skills $04(02 \%)$ respondents respectively opted for no opinion, disagree and regarding strongly disagree categories of opinion. Lastly, $26(13 \%)$ respondents were of the opinion that training has enhanced your skills to cope wt tTraining difficult situations. Among these 26 respondents, 09 (4.5\%) and 1 beduced $(6.5 \%)$ respondents strongly agreed and agreed with the statemenyour job respectively.

Besides, the cross comparison enumerates that skill development is anxiety and one of the basic aims of training whereby the respondents agreed that trustration their skill level improved as a result of participation in training. In this regard, in the column wise distribution, $55.5 \%$ respondents strongly agreed with statements given in the table while $35.5 \%$ agreed. Thus, a total of $91 \%$ respondents were of the opinion that skill development is an essential component of training and respondents' skills were developed as a result of participation in training. Additionally, in row wise distribution $70 \%$ of respondents opt for the statement that training has enhanced their skill regarding specific job task. In addition, the chi-square test validates the argument that skills and presentation style of trainers have an important role in effectiveness of training. The chi-square value of 20.987 having degree of freedom of 06 shows that the argument is highly significant.

Thus it is concluded that training enhanced that skills of teachers participating in training. In this context, communication, job specific and skill to deal with specific situation are enhanced as a result of training.

\section{raining and job related impacts}

It is critical for any organization to improve the skills, expand knowledge and reduce the anxiety of the employees in order to increase satisfaction as well as productivity. In explanation, existing literature indicates that individuals seek equity in their jobs where higher rates of unequal and unfair treatment will lead to anxiety, tensions and disequilibrium experienced by the person (Yamnill and McLean, 2001). Further, Transfer of training is the main part in training effectiveness program. It is found that transfer of training generally refers to the use of trained knowledge and skills back on the job (Punia and Kant, 2013). It is also evident that industrial training program helps students to increase there the knowledge, skills and attitudes (Mat et al, 2011). Anxiety plays its own role in effecting performance of employees during job (Colquitt et al, 2000) where one of the core benefits of training is the eradication or reduction of anxiety and frustration during new job. In this context, training enables one to adopt to new environment and job behavior. Training also makes enable employee to come up with new work demands and develop their skill (Chen et al, 2004). In a similar context, field information given in the table below is an explanation of impacts of training conduction on job related aspects through multiple dimensions (see the table below)

Table 8: Training and Job related Impacts

\begin{tabular}{l|l|l|l|l|l|l|}
$\begin{array}{l}2 \phi 0 \text { Statements } \\
(10\end{array}$ & $\begin{array}{l}\text { Strongly } \\
\text { Agree }\end{array}$ & Agree & $\begin{array}{l}\text { No } \\
\text { opinion }\end{array}$ & Disagree & $\begin{array}{l}\text { Strongly } \\
\text { Disagree }\end{array}$ & Total \\
\hline $\begin{array}{l}\text { Training } \\
\text { has }\end{array}$ & $\begin{array}{l}34(17 \\
\text { expanded }\end{array}$ & $\begin{array}{l}13 \\
(6.5\end{array}$ & $\begin{array}{l}00(00 \\
\%)\end{array}$ & $\begin{array}{l}00(00 \\
\%)\end{array}$ & $\begin{array}{l}00(00 \\
\%)\end{array}$ & $\begin{array}{l}\mathbf{4 7} \\
\mathbf{( 2 3 . 5} \\
\%)\end{array}$ \\
\hline
\end{tabular}




\begin{tabular}{|l|l|l|l|l|l|l|}
\hline Total & $\begin{array}{l}110(55 \\
\%)\end{array}$ & $\begin{array}{l}78(39 \\
\%)\end{array}$ & $\begin{array}{l}05(2.5 \\
\%)\end{array}$ & $\begin{array}{l}04(02 \\
\%)\end{array}$ & $\begin{array}{l}03(1.5 \\
\%)\end{array}$ & $\begin{array}{l}200 \\
(100 \\
\%)\end{array}$ \\
\hline
\end{tabular}

Training conducted by an organization is solely for the purpose of increasing the skills, polishing the capability and potential of its employs where the conduction of training has many impacts on employs. The above table is an explanation of impacts of training conduction on their job related aspects through multiple indicators. In this regard, expansion of knowledge about job is an important aspect of training conduction where $47(23.5 \%)$ respondents opt for the statement. Among these 47, $34(17 \%)$ and 13 (6.5\%) respondents strongly agreed and agreed with the statement in order while none of the respondents disagreed which indicates the importance of training in expansion of knowledge about a job. 45 (22.5\%) respondents were of the opinion that training has changed their attitude towards job whereby $10(05 \%)$ and $28(14 \%)$ respondents strongly agreed and agreed with the statement respectively. $28(14 \%)$ respondents stated that training has improved their skills regarding the job whereby 17 $(8.5 \%)$ and $10(05 \%)$ respondents strongly agreed and agreed with the statement in order. To finish, a reasonable portion i.e. $80(40 \%)$ respondents argued that training has reduced their job related anxiety. Among these 80, $47(23.5 \%)$ and $27(13.5 \%)$ respondents strongly agreed and agreed with argument which strongly indicates that training conduction leads to reduction in job related anxiety.

Besides, the cross comparison shows that training have numerous job related impacts on trainees. In this connection, in the column wise distribution, $55 \%$ respondents strongly agreed with statements given in the table while $39 \%$ agreed. Thus, a total of $94 \%$ respondents were of the opinion that training has many positive job related impacts. Besides, in row wise distribution $80 \%$ of respondents opt for the statement that Training reduced your job related anxiety and frustration. In addition, the chi-square test validates the argument that skills and presentation style of trainers have an important role in effectiveness of training. The chi-square value of 86.00 having degree of freedom of 06 shows that the argument is highly significant. It is concluded from the discussion that training have many job related impacts on teachers. In this regard, the participants were of the opinion that training expanded their knowledge, changed their attitude towards job and reduced job related anxiety.

\section{Conclusion}

The current research activity is an effort to study the impact of trainings on job performance of teachers in public sector colleges in Khyber Pakhtunkhwa. The study is purely quantitative in nature and conducted in Malakand Division, Khyber Pakhtunkhwah, Pakistan. Probability sampling technique has been adopted for sampling specifically stratified random sampling while a structured questioner based on Likert five category scales has been utilized to collect information from the selected samples. Besides, the data has been analysed in tabular form including frequency and percentage against each category of opinion. In addition, chi-square test has been applied to in order to check association among variables. The process of data analysis has been done through computer based software named as statistical packages for social sciences (SPSS). The basic aim of any training conduction is learning and evaluation of the learning is important while analysing impacts. Participants were of the opinion that they were clear about specific objectives of the training, learned the specific objectives of the training as well as the training process was able to meet specific objectives of the training. Another indicator in this context was the skill development as a result of training whereby the participant argued that training has enhanced their communication skills, enhanced their skills regarding specific job task and the skills to cope with difficult situations. Besides, to evaluate the training it was eminent to know the impacts of training on job. In this connection, the findings enumerate that training had many job related impacts on trainees including expansion of knowledge about the job, change in attitude towards job, increase in skills regarding the job and reduction in job related anxiety and frustration. The findings reveal that training significantly affects trainee's behaviour and performance. In context of impact of training on behaviour, participants argued that training has changed their behaviour such as their behaviour with colleagues has gone descent. Besides, the study indicates that training contributes significantly to better in performance of participants. In this connection, the overall performance of participants gone better and betterment in job specific performance was observed along with increase in productivity. Lastly, the training had numerous conclusive effects on participants including increase in efficacy, betterment in quality of productivity.

\section{References}

Baldwin, T. and Magjuka, R.J. (1988). "Transfer of Training: A Review and Directions for Future Research”, Personnel Psychology, 41, pp. 63-105.

Babbie, E. (2005). The Practice of Social Research (Third ed). Thomson Wadsworth, USA. P. 413.

Bassi, L.J. \& Van Buren, M.E. (1999). Sharpening the leading edge. In training and development. 53(1):23-32.

Bumpass, S. (1990). "Measuring Participant Performance - An Alternative", Australian Journal of Educational Technology, 6(2), pp. 99-107.

Babbie, E. (2012). The basics of social research. New York; McGraw-Hill Company.

Barber, M. and Mourshed, M. (2007) How the world's best-performing school systems come out on top, McKinsey \& Co.

Chen, T.Y., Chang P.L. and Yeh, C.W. (2004). "A Study of Career Needs, Career Development Programs, Job Satisfaction and the Turnover Intensity of R \& D Personnel”, Career Development International, 9(4), pp. 424-437.

Colquitt JA, LePine JA, Noe RA. 2000. Toward an integrative theory of training motivation: a meta-analytic path analysis of 20 years of research. J. Appl. Psychol. 85:678-707

Dawson, C. (2002). Practical Research Methods. How To Books, Newtec Place, Magdalen Road, Oxford OX4 1RE, United Kingdom.

Denzin, N. 1978, The Research Act: A Theoretical Introduction to Sociological Methods, New York: McGraw-Hill.

Goldstein I. L. Ford J. K. (2002). Training in Organizations. Belmont, CA:Wadsworth. 4th ed.

Gomez, L.M., David, B., \& Robert, C. (2011). Managing Human Resources (7th edition). Englewood cliffs, NJ: Prentice-Hall, Inc. Pages:371-373

Hinkim, T. R, and Schriesheim, C. A (2004) "If u don't hear from me you know you are doing fine the effects of managenment nonresponse to employee performance" .Cornell hotel and restaurant administration quarterly November 2004 pp362-372

Kirkpatrick, D. L. (1976). Evaluation of Training, Training and development handbook: A guide to human resource development, New York; McGraw-Hill Company.

Kendal, D. (2007). Sociology: the essentials. Thomson-wadsworth publications.

Nadeem, M (2010). Role of Training in Determining the Employee Corporate Behavior with Respect to Organizational Productivity: Developing and Proposing a Conceptual Model. International Journal of Business and Management Vol. 5, No. 12. www.ccsenet.org/ijbm.

Nueman, L. (2006). Quantitative and qualitative research methods. Pearson publications India.

Punia.,\&Saurabh Kant. (2013). A Review of Factors Affecting Training Effectiveness vis- à-vis Managerial Implications and Future Research Directions. International Journal of Advanced Research in Management and Social Sciences, 2(1),151-164

Paradise, A. (2007). State of the Industry: ASTD's Annual Review of Trends inWorkplace Learning and Performance. Alexandria, VA: ASTD

Rama, M. Janaki. and Vaishnavi. R. (2012). "Measuring Training Effectiveness: A Study in a Leading Retailing Industry in A Metropolitan City", International Journal of Multidisciplinary Management Studies, 2(4), pp. 16-25.

Richard, P.N., Thacker, J.W., \& Way, S.A. (2002). Training evaluation: Perspectives and evidence from Canada. Indian Journal of Industrial Relations, 33(3), 295-304

Sahinidis, Alexandros G. and Bouris, J. (2008). "Employee Perceived Training Effectiveness Relationship to Employee Attitudes", Journal of European Industrial Training, 32(1), pp. 63-76.

Saks, A. and Haccoun, R. (2007). Managing Performance through Training and Development, Toronto, Nelson and Thompson Ltd. 
Santos, A. and Stuart, M. (2003). "Employee Perceptions and Their Influence on Training Effectiveness", Human Resource Management Journal, 13(1), pp. 27-45.

Sekaran,V.(2003).Methods in Business Research. 4th edition, Prentice Hall Publishers

Sekaran,V.(2003).Methods in Business Research. 4th edition, Prentice Hall Publishers

Satterfield $\mathrm{JM}^{1}$, Hughes E. (2007). Emotion skills training for medical students: a systematic review. Med Educ. 2007 Oct;41(10):935-41.

Tabassi, Amin A., Mahyuddin, R. and Abu, Hassan A.B. (2012). "Effects of Training and Motivation Practices on Teamwork Improvement and Task
Efficiency: The Case of Construction Firms", International Journal of Project Management, 30(2), pp. 213-224.

Taylor PJ, Russ-Eft DF, Chan DWL. 2005. A meta-analytic review of behavior modeling training. J. Appl. Psychol. 90:692-709

Tharenou P, Saks AM,Moore C. 2007. A review and critique of research on training and organizational-level outcomes. Hum. Resour. Manag. Rev. 17:251-73

Singh, K. (2007). Quantitative Social Research Methods. Sage Publications.

Yamnill, S. \& McLean, G.N. (2001). Theories supporting transfer of training. Human Resource Development Quarterly, 12(2), 195-208.

Word Web (2014). Word web info.com. 